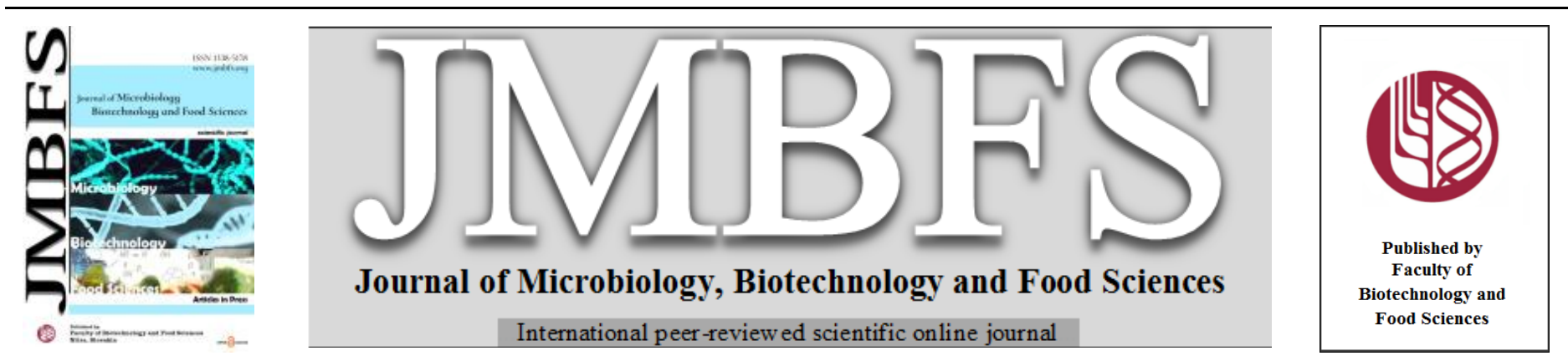

\title{
THE IN VITRO ANTAGONISTIC EFFECTS OF SOME BACILLUS SPP. ON THE GROWTH AND MYCOTOXIN PRODUCTION OF TOXIGENIC ASPERGILLI
}

\author{
Miroslava Hlebová*1, Viktória Uzsákovál,2, Ivana Charousová ${ }^{3}$, Lukáš Hleba ${ }^{2}$ \\ Address(es): Ing. Miroslava Hlebová, PhD. \\ ${ }^{1}$ University of SS. Cyril and Methodius, Faculty of Natural Sciences, Department of Biology, Nám. J. Herdu 2, SK-91701, Trnava, Slovak Republic. \\ ${ }^{2}$ Slovak University of Agriculture in Nitra, Institute of Biotechnology, Faculty of Biotechnology and Food Sciences, Tr. A. Hlinku 2, 94976, Nitra, Slovak Republic. \\ ${ }^{3}$ Clinical Microbiology Laboratory, UNILABS SLOVENSKO, s.r.o., J. Bellu 66, Likavka, Slovak Republic.
}

*Corresponding author: miroslava.hlebova@ucm.sk

https://doi.org/10.15414/jmbfs.5412

\section{ARTICLE INFO}

Received 16. 6. 2021

Revised 6. 10. 2021

Accepted 13. 10. 2021

Published 1. 12. 2021

Regular article

OPEN $\partial_{\text {ACCESS }}$

\section{ABSTRACT}

This study aimed to investigate the antagonistic effect of three strains of the genus Bacillus on toxigenic fungi contaminating food commodities, with emphasis on two ochratoxigenic isolates (A. ochraceus, A. westerdijkiae) and two aflatoxigenic isolates (A. flavus and A. parasiticus). In vitro studies were carried out using two different methods for cultivation tested bacilli with fungal isolates coincubation and dual culture method. The most sensitive isolate was A. ochraceus by both used methods. B. mycoides $(5.72 \pm 6.4 \mathrm{~mm})$ and $B$. subtilis $(5.08 \pm 2.84 \mathrm{~mm}$ ) were able to inhibit its growth and sporulation during ten days of cultivation (both inhibited the sporulation of $A$. ochraceus $100 \%$ ) in coincubation. The most effective in the dual culture method were B. subtilis and B. thuringiensis against $A$. ochraceus (growth inhibition rate $84.40 \% ; 90.55 \%$ ) and A. flavus (growth inhibition rate $91.54 \%$; $92.43 \%$ ). The most effective sporulation inhibitors were B. subtilis and B. thuringiensis, which completely inhibited the sporulation of A. ochraceus and A. parasiticus after ten days of coincubation. Likewise, all tested bacterial strains showed complete inhibition of ochratoxin A synthesis in A. ochraceus and A. westerdijkiae exposure to bacterial volatiles. So, the current study illustrated that strains of the genus Bacillus could significantly inhibit the growth, sporulation, and mycotoxin production of toxigenic aspergilli and showing the great potential as a biocontrol agent of preand post-harvest food diseases caused by microscopic filamentous fungi.

Keywords: antagonistic activity, Bacillus spp., direct contact, mycotoxins, toxigenic aspergilli, volatiles

\section{INTRODUCTION}

Food spoilage, mainly microbial spoilage, is a major worldwide problem for the food industry, leading to the waste of edible foods and economic losses for producers and consumers (Lorenzo et al., 2018). Among microorganisms, filamentous fungi are the primary food contaminants, which can occur at various stages of the food chain (pre-/post- harvest, during processing, or storage) (Sadiq et al., 2019). The development of fungi on or in food leads to changes in sensory properties of food, ranging from visual damage to noticeable changes in smell, taste, or texture, but can also have negative effects on human and animal health through the production of mycotoxins (Badiale Furlong et al., 2021). To prevent the deterioration of food crops and foodstuffs by fungal contaminants and their mycotoxins and thus prolong the shelf life of the products, different methods are used to eliminate them. This includes the use of fungicides, chemical preservatives, and various other chemical and physical methods. Despite their effectiveness, there are some limitations in using these methods due to their high cost, possible production of by-compounds with higher toxicity, loss of nutritional value of food (Karlovsky et al., 2016; Neme and Mohammed, 2017). In the view of the above context, there is a growing interest in the use of biological agents as preservatives in the field, processing, and postharvest handling has achieved the attention of the scientific community because they offer the best alternative to control fungi in food. The use of antagonist microorganisms or their secondary metabolites has proven to be safe and effective in the biological control of growth inhibition of many fungal pathogens (Ramos-Pereira et al., 2021; Zhang et al., 2021).

The bacterial genus Bacillus is a promising candidate for a fungal antagonist in the sphere of bioprotection and bioconservation of food (Nath et al., 2015). The importance of this genus is associated with the biological control of numerous fungal pathogens contaminating many food commodities (Islam et al., 2019). There are several mechanisms for the use of Bacillus species to control food fungal pathogens, including competition in space or nutrients, antibiosis, and induced systemic plant resistance (Lastochkina et al., 2019). One of these mechanisms, antibiosis, has been reported as an essential mechanism by which the genus
Bacillus produces active metabolites that inhibit fungal contaminants. Antifungal lipopeptides, volatile organic compounds produced by species of the genus Bacillus, are mainly biologically active substances used to inhibit fungal growth (Fira et al., 2018; Saleh and Jaoua, 2020). The role of Bacillus strains is not limited only to inhibiting fungal growth, but some species can also interact with fungal mycotoxins, resulting in their inactivation or removal through cell wall binding. These mechanisms, which help eliminate mycotoxins, include biodegradation of mycotoxins by chemical or enzymatic cleavages and adsorption, where the prominent role is played by the cell wall components of the microorganism (Chen et al., 2018).

This study was designed to investigate in vitro inhibition effects of Bacillus spp. by using two different methods, coincubation and dual culture method, against the growth, sporulation, and mycotoxin production of four toxigenic isolates of the genus Aspergillus (A. ochraceus, A. westerdijkiae, A. flavus, and A. parasitcus).

\section{MATERIAL AND METHODS}

Bacterial strains, identification, growth condition and inoculum preparation

Three strains of the genus Bacillus, namely B. subtilis, B. mycoides and $B$. thuringiensis were used in this study. The antagonistic bacteria of the genus Bacillus were obtained from food samples (B. mycoides and B. subtilis) and from soil samples (B. thuringiensis). Before identification, the strains were cultivated on nutrient broth (Imuna, Slovakia) at $30{ }^{\circ} \mathrm{C}$ for $24 \mathrm{~h}$. Identification of the bacterial strains was performed by MALDI TOF MS (Bruker Daltonics, Germany, Maldi Biotyper) using single colonies of $24 \mathrm{~h}$ cultures of each strain according to Hleba et al. (2017). To prepare a bacterial inoculum the bacterial strains were cultivated 24 hours at $30{ }^{\circ} \mathrm{C}$ in meat peptone broth (MPB) (HiMedia, India). Subsequently, the bacterial inoculum was prepared by diluting the bacterial suspension in sterile phosphate saline to a final concentration of $10^{6}$ cells $/ \mathrm{ml}$ by adjusting the density to $0.5 \mathrm{McFarland}$ units. 


\section{Fungal isolates, identification, growth condition and inoculum preparation}

The following toxigenic isolates of fungi were used in this study: Aspergillus flavus, A. parasiticus, A. ochraceus and A. westerdijkiae. All the fungal isolate were obtained from green coffee beans samples, marketed in Slovakia. The isolates were identified to the species level according to morphological characteristics based on microscopy used follow diagnostic literature: Samson et al., 2002, Chen et al., 2017, Frisvad et al., 2019 and Yamairi et al., 2019. Aspergillus isolates were tested for aflatoxin $\mathrm{B}_{1}$ and $\mathrm{G}_{1}$, and ochratoxin $\mathrm{A}$, and their production was confirmed by thin layer chromatography (TLC) (Labuda and Tancinová, 2006) To prepare a fungal inoculum the isolates were cultivated on Sabouraud dextrose agar (SDA) (HiMedia, India) for 5 days at $25^{\circ} \mathrm{C}$. Then the inoculum was prepared according to Císarová et al. (2020) to a final concentration $10^{6} \mathrm{CFU} / \mathrm{mL}$ by adjusting the density to $0.7-1.2 \mathrm{McF}$ arland units, depending on the strain.

\section{In vitro screening antagonistic activity of Bacillus spp. by volatiles}

The antifungal activity of volatiles potentially produced by Bacillus species against toxicogenic Aspergillus species (Aspergillus flavus, A. parasiticus, A. ochraceus and $A$. westerdijkiae) was tested using the coincubation method (Ul Hassan et al., 2019), with some modification (Fig 1). A $100 \mu$ of the prepared bacterial inoculum suspension $\left(10^{6}\right.$ cells $\left./ \mathrm{ml}\right)$ was applied on MPA plates (Meat peptone agar; HiMedia, India) and cultivated without sealing for 24 hours at $30{ }^{\circ} \mathrm{C}$. After 24 hours, the cover of the bacterial plate was replaced by a base SDA plate containing $5 \mu \mathrm{l}$ of fungal inoculum $\left(10^{6} \mathrm{CFU} / \mathrm{ml}\right)$. Subsequently, both parts of the plates were tightly sealed with parafilm to prevent volatiles escape. The plates were cultivated for 10 days at $30{ }^{\circ} \mathrm{C}$ in the dark. The plates were cultivated in an inverted position (the plate containing the bacterial inoculum was on top). The control treatment was represented by fungus inoculated plates without bacterial inoculum. The effects of bacterial volatiles on fungal growth and sporulation were evaluated by measured diameters $(\varnothing \mathrm{mm})$ of the growing fungal colonies at the $2^{\mathrm{n}} \mathrm{d}, 4^{\text {th }}, 6^{\text {th }}, 8^{\text {th }}$, and $10^{\text {th }}$ day of cultivation with a digital caliper. All analyzes were performed in 6 replicates.

To evaluate the reversibility effects of bacteria volatiles on the fungal growth, on the $5^{\text {th }}$ day of cultivation, a small piece of a fungal colony $(\varnothing 10 \mathrm{~mm})$ from the margin was removed with a sterile cork borer and transferred to fresh SDA plates. These plates were incubated for 10 days at $30{ }^{\circ} \mathrm{C}$, and mycelial growth and sporulation were monitored (in the same way as before on $2^{\text {n }} d, 4^{\text {th }}, 6^{\text {th }}, 8^{\text {th }}$ and $10^{\text {th }}$ day) and compared with the control group (plates with fungal inoculum never exposed to bacterial volatiles)

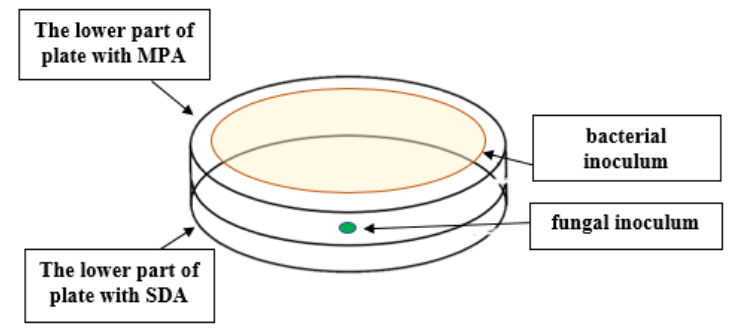

Figure 1 The scheme of coincubation method

In vitro screening antagonistic activity of Bacillus spp. by contact

The strains of genus Bacillus were also evaluated in vitro for their antagonistic properties against toxicogenic Aspergillus species by using dual culture technique according to Rajkumar et al. (2018) with slight modification (Fig. 2). Firstly, the Petri dishes $(\varnothing 60 \mathrm{~mm}$ ) with PDA (Potato dextrose agar, HiMedia, India) were divided in half by a dividing line and then were inoculated with the bacterial inoculum $\left(10^{6}\right.$ cells $\left./ \mathrm{ml}\right)$ by spreading (comma) approximately $1 \mathrm{~cm}$ from the center of the plate dividing line to the left side of plates. After 24 hours of cultivation at $30{ }^{\circ} \mathrm{C}$ in the dark, the plates were inoculated with fungal inoculum $(1 \mathrm{~cm}$ from the center of the plate dividing line). Each fungus was inoculated to the right side of plates with inoculation needle. The antagonistic activity of the Bacillus spp. was monitored in comparison with a control sample (plates with fungal inoculum in the absence of bacteria). The prepared plates were sealed with parafilm and cultivated at $30{ }^{\circ} \mathrm{C}$ for 8 days. The mycelial growth of fungi was recorded with a digital caliper on the $2^{\text {nd }}, 4^{\text {th }}, 6^{\text {th }}$, and $8^{\text {th }}$ day of cultivation in $\mathrm{mm}$. The Percentage of Mycelial Growth Inhibition (PGMI) of the tested species was calculated using the following equation:

$$
\mathrm{PGMI}=((\mathrm{FC}-\mathrm{FB}) / \mathrm{FC}) * 100
$$

where FC is the growth of the fungal mycelium control (measured in $\mathrm{mm}$ from the inoculation point to the edge of the mycelial colony), $\mathrm{FB}$ is the growth of the fungal mycelium in the presence of bacteria (measured in $\mathrm{mm}$ from the inoculation point to the edge of the mycelial colony towards the antagonist). All analyzes were performed in 6 replicates.

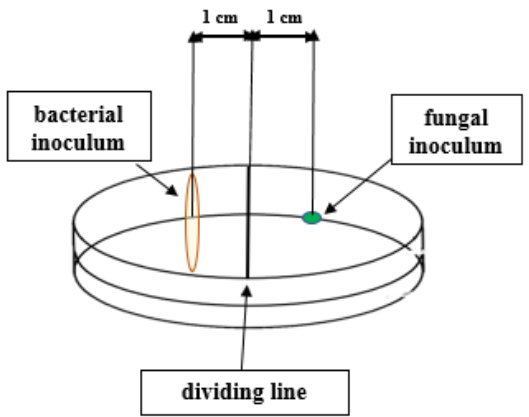

Figure 2 The scheme of dual cultivation method

\section{Antitoxigenic effect of Bacillus spp.}

The antitoxigenic effect of the genus Bacillus was evaluated only after coincubation method (including the reversibility test). For the detection of mycotoxins, the qualitative TLC (thin layer chromatography) screening method according to Labuda and Tančinová (2006) was used. After 10 days of cultivation (coincubation and reversibility) the ability of the genus Bacillus to suppress the production of aflatoxin $\mathrm{B}_{1}\left(\mathrm{AFB}_{1}\right)$ in A. flavus, $\mathrm{AFB}_{1}$ and aflatoxin $\mathrm{G}_{1}\left(\mathrm{AFG}_{1}\right)$ in A. parasiticus and ochratoxin A (OTA) produced by $A$. westerdijkiae and $A$. ochraceus was evaluated. The used method is described in Císarová $\boldsymbol{e t ~ a l . ~ ( 2 0 1 5 ) ~}$

Visualization of mycotoxins $\mathrm{AFB}_{1}, \mathrm{AFG}_{1}$, ochratoxin $\mathrm{A}$ and their authentic standards (Sigma Aldrich, Germany) was performed directly under a UV lamp at $366 \mathrm{~nm}$, where aflatoxin $\mathrm{B}_{1}$ and ochratoxin $\mathrm{A}$ appeared as a blue spot and $\mathrm{AFG}_{1}$ as a green spot.

\section{Statistical analysis}

Obtained results were evaluated by analysis of variance (one-way ANOVA) and Tukey HSD 95\% multiple range test $(p<0.05)$ using the program STATGRAPHICS Centurion XVI (version 16.1.11). The results of the percentage inhibition of spore germination and percentage of the mycelial growth inhibition (PMGI \%) were calculated by using the MS Office Excel 2016 program.

\section{RESULTS AND DISCUSSION}

\section{Antagonistic activity of the genus Bacillus}

Contamination of food with various perishable microorganisms, mainly microscopic filamentous fungi, is a global problem that leads to large-scale economic losses. Nowadays, synthetic preservatives or antifungals are used to prevent their growth in food. However, these substances can affect humans and the environment, so more environmentally friendly alternatives are still being sought (Foysal et al., 2018; Morita et al., 2019; Zhang et al., 2020). Biological control of fungal growth and food deterioration by antagonist bacteria such as Bacillus spp. is an alternative to the chemical preservatives used. Many previous studies have reported that substances produced by some Bacillus species have antifungal activity against a broad range of fungi such as Botrytis cinerea (Touré et al., 2004) Fusarium graminearum (Wang et al., 2007), Alternaria solani (Zhang et al. 2020), including the genus Aspergillus (Jiang et al., 2014; Arfaoui et al., 2018). In this study, three strains of the genus Bacillus (B. subtilis, B. mycoides, B. thuringiensis) were assayed against four isolates of ochratoxigenic ( $A$. westerdijkiae and A. ochraceus) and aflatoxigenic (A. flavus and A. parasiticus) aspergilli using two different methods. The first coincubation method investigated the antifungal activities of potentially produced volatiles of the genus Bacillus. The second method was used to evaluate the antifungal activity of Bacillus spp. by the method of dual culture, where the tested bacilli were inoculated on one plate together with the fungi and were in contact with each other. Furthermore, there are many reports focused on the antioxygenic potential of the genus Bacillus (Taniwaki et al., 2018; Ren et al., 2020; Higazy et al., 2021). So, the inhibition effect of tested bacilli on the production of mycotoxins was evaluated in this study, too.

Effect of Bacillus spp. on the growth and sporulation of tested fungi by bacterial volatiles

The result of the coincubation method showed that in the presence of the Bacillus spp. and their released volatiles, the growth of tested fungi was inhibited significantly $(p<0.05)$. The strains showed different antagonistic activity on mycelia growth and sporulation of toxigenic aspergilli. A. ochraceus was the most sensitive isolate from the tested ochratoxigenic fungi. B. mycoides $(5.72 \pm 6.4 \mathrm{~mm})$ and $B$. subtilis $(5.08 \pm 2.84 \mathrm{~mm})$ were able to inhibit vegetative growth and sporulation during ten days of cultivation (both inhibited the sporulation of $A$ 
ochraceus $100 \%$ ) of this isolate significantly. After ten days of coincubation with these species, the radial growth of $A$. ochraceus resulted in smaller colony diameters compared to the control set $(13.18 \pm 7.07 \mathrm{~mm})$. B. thuringiensis showed the ability to inhibit this species only until day 6 of cultivation (Fig. 1A) with the inhibition of sporulation 33,33\%. The better results for B. thuringiensis were noted by Arfaoui et al. (2019). They found that B. thuringiensis J4F was able to inhibit $78 \%$ of A. ochraceus growth. Also, partial inhibition of A. westerdijkiae was found in treatment with $B$. thuringiensis $(20.75 \pm 12.44 \mathrm{~mm})$ compared to a control set $(23.65 \pm 12.65 \mathrm{~mm})$. However, B. thuringiensis did not show any inhibitory effect on A. westerdijkiae sporulation (Table 1). B. subtilis and B. mycoides were the most effective species in inhibiting the growth of this isolate. Antagonism of $B$. subtilis by volatiles was studied in work of Petchkongkaew $\boldsymbol{e t ~ a l . ~ ( 2 0 0 8 ) . ~ T h e y ~ f o u n d ~ t h a t ~}$ the growth of A. westerdijkiae tested by the coincubation method for seven days was lower, about $34 \%$. Inhibition of growth was associated with prolongation of the lag phase of the microscopic fungus, thereby reducing its ability to compete and utilize the nutrients in the environment. Also, Einloft et al. (2017) observed the inhibitory effect of B. safeness RF69, B. amyloliquefaciens RP103, and B. subtilis RP242 on the growth of $A$. westerdijkiae as well as their ability to inhibit spore formation. They found that $B$. subtilis RP242 was the most effective biological control agent of fungal growth and sporulation. The results showed a $95.6 \%$ reduction in growth and spore germination after ten days of coincubation.
A)

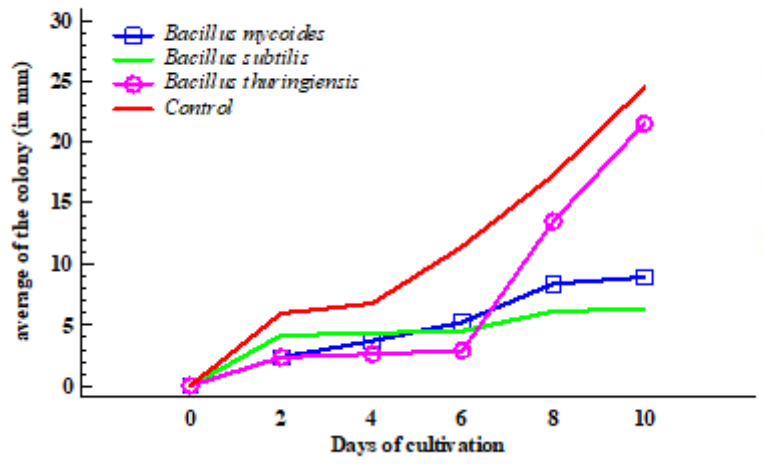

B)

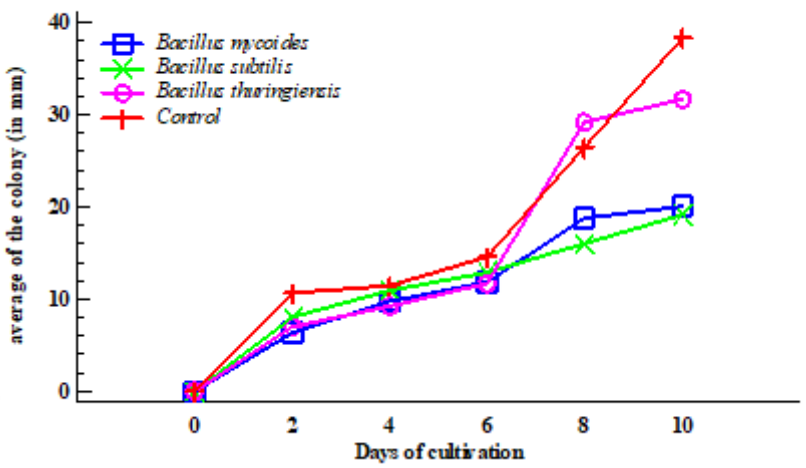

Figure 1 The antagonistic effect of the tested Bacillus spp. on the growth: A) A. ochraceus $(\mathrm{n}=6)$ and B) A. westerdijkiae ( $\mathrm{n}=6$ ) during 10 days of cultivation in the dark (in mm) at $30^{\circ} \mathrm{C}$

The inhibition activity of Bacillus spp. on the growth and sporulation of aflatoxigenic aspergilli was much more potent, especially for A. flavus isolate. Results showed that among all tested toxinogenic fungi of the genus Aspergillus, A. flavus was the most sensitive to the action of bacterial antagonists. The mycelial growth of A. flavus reached the smallest averages throughout all periods of cultivation (10 days), mainly in the presence of $B$. subtilis $(1.60 \pm 1.87 \mathrm{~mm})$ and B. thuringiensis $(0.85 \pm 1.15 \mathrm{~mm})$ (Fig. 2A). Nayak et al. (2020) tested the antifungal activity of 4 isolates of Bacillus spp. against the growth and sporulation of two strains of A. flavus (A2, A28). Their results showed that Bacillus vallismortis $\mathrm{BC} 5$ was the most potent in mycelial growth inhibition of $A$. flavus (92.3\%), followed by B. subtilis BC6 (90\%) and B. amyloliquefaciens BC1 and BC2 $(88.6 \%$ and $89.3 \%)$. However, in our study, their efficacy did not correlate with inhibition of sporulation. $B$. subtilis showed no inhibitory effect on sporulation, and the effect of $B$. thuringiensis on A. flavus sporulation was minimal (16.67\%) (Table 1). On the contrary, in their study, Gong et al. (2014) found the high inhibitory activity of $B$. subtilis on the sporulation of A. flavus. They found that bacillomycin D produced by B. subtilis fmbJ strain (CGMCCN 0943) inhibited sporulation of A. flavus from $85.72 \%$ to $98.10 \%$.

A)

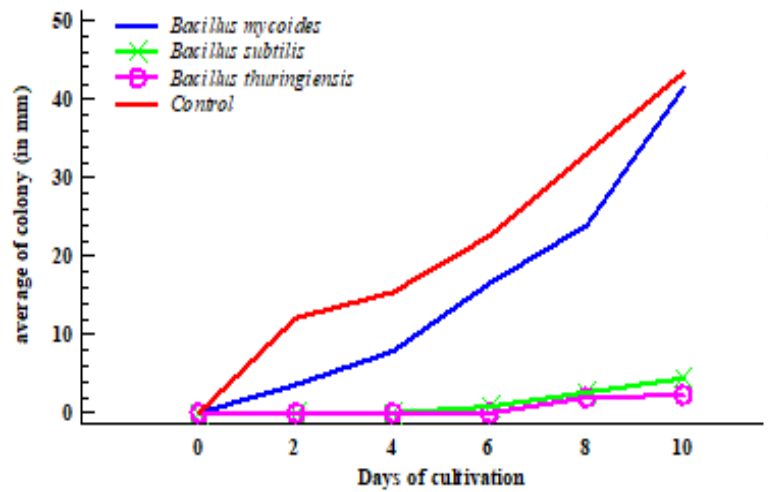

In this study, $100 \%$ inhibition of sporulation was observed in treatment with $B$. mycoides, but this species had only a mediatory inhibition effect on A. flavus growth after ten days of cultivation $(18.72 \pm 13.98 \mathrm{~mm})$ in comparison with a control set $(29.55 \pm 10.20 \mathrm{~mm})$. On the other hand, B. subtilis and B. thuringiensis in comparison to the control and A. flavus species had better inhibitory effects on the sporulation of A.parasiticus (100\%), but these species inhibited its growth only moderately (Fig. 2B). The best inhibitory effect for A. parasiticus was found in treatment with $B$. mycoides $(6.11 \pm 3.78 \mathrm{~mm})$ during the whole cultivation period (10 days). However, B. mycoides was not able to inhibit $A$. parastiticus sporulation (Table 1). Also, Chaves-Lopez et al. (2015) evaluated the antifungal activity of the volatile organic compounds (VOCs) produced by 75 different food-borne Bacillus species against Aspergillus niger Aspergillus flavus, Aspergillus parasiticus, Aspergillus clavatus, Fusarium oxysporum f. sp. lactucae and Moniliophthora perniciosa. In their study, the species A. clavatus MG103 and A parasiticus MG51 showed the least susceptibility. Similar to our study, the growth of these species was not affected by Bacillus spp. volatiles production.

Figure 2 The antagonistic effect of the tested Bacillus spp. on the growth: A) A. flavus $(\mathrm{n}=6)$ and $\mathrm{B})$ A. parasiticus $(\mathrm{n}=6)$ during 10 days of cultivation in the dark (in $\mathrm{mm}$ ) at $30^{\circ} \mathrm{C}$ 
Table 1 Inhibition of sporulation of tested aspergilli by Bacillus spp. after 10 days at $30{ }^{\circ} \mathrm{C}$ of coincubation method

\begin{tabular}{lcccc}
\hline \multirow{2}{*}{ Tested bacilli } & \multicolumn{4}{c}{ Tested aspergilli } \\
\cline { 2 - 5 } & A. ochraceus & A. westerdijkiae & A. flavus & A. parasiticus \\
\hline \multirow{3}{*}{ Bacillus subtilis } & 100.00 & Inhibition of sporulation $(\%)$ \\
Bacillus mycoides & 100.00 & 50.00 & 0.00 & 100.00 \\
Bacillus thuringiensis & 33.33 & 66.67 & 100.00 & 0.00 \\
Control of tested fungi & - & 0.00 & 16.67 & 100.00 \\
\hline
\end{tabular}

Legend: -: no effect (without presence of Bacillus strains)

The cell wall of fungi is necessary for their homeostasis, and various environmental or antifungal stresses can cause modifications such as suppression of sporulation, insufficient development of hyphae, or pigmentation losses (Garcia-Rubio et al., 2020). In this study, similar changes were observed. Compared to the control, some fungal isolates whose sporulation was partially or entirely suppressed showed an observed change or loss of mycelial pigmentation (Fig. 3).
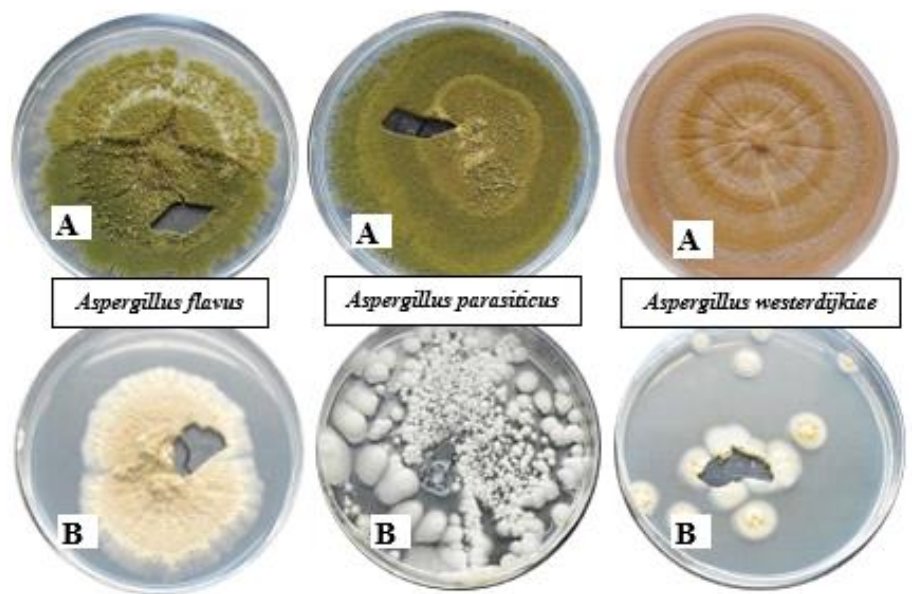

Figure 3 Changes observed in mycelial pigmentation: A) normal fungal mycelium (never exposed to bacterial volatiles) (control); B) change of mycelial pigmentation after treatment with volatiles of tested bacilli
After five days of coincubation with individual species of bacilli, the cultured plates were opened, and one small pieces of fungal mycelia were removed and subsequently cultivated on fresh SDA plates for another ten days without the presence of tested bacteria. However, upon transfer to the fresh SDA media, in the absence of bacterial volatiles, all the fungal isolates showed normal growth and sporulation, comparable with control sets. Our results showed that the inhibition was poor and that the coincubation of fungi with the volatiles of tested bacilli during the 5-days was insufficient for more significant inhibition of their growth and sporulation. For this reason, the obtained results are not presented in this work Similar results were obtained by UI Hassan et al. (2019) with Bacillus spp. against tested fungi and Fiori et al. (2014) who treated toxigenic A. carbonarius MPVA566 and A. carbonarius AN6 with antagonistic yeast Candida friedrichii 778. Also, in the study of Saleh $\boldsymbol{e t}$ al. (2021), similar reversibility in mycelial growth and sporulation was observed in toxigenic fungi included A. flavus CECT, 2687after removal from volatiles of B. megaterium BM344-1. So, these results suggested that the microbial volatiles effect was insufficient and that bacterial volatiles were continuously required to allow effective biocontrol of spoilage fungi.

\section{Effect of Bacillus spp. on the growth of tested fungi by contact}

In the dual culture method, only the effect of Bacillus species on the growth of toxigenic fungi was observed. The results of dual culture method showed that antifungal ability of bacilli had a certain inhibitory potential on the growth of all tested fungal isolates. Significant differences $(p<0.05)$ between the antagonistic effect of tested bacilli were found (Table 2). B. mycoides showed the best inhibitory ability against toxigenic aspergilli.

Table 2 Antifungal activity (colony diameter in $\mathrm{mm} \pm \mathrm{SD}$ ) of Bacillus spp. on the growth of tested aspergilli ( $\mathrm{n}=6$ ) by dual culture method, after 8 days of incubation in the dark at $30^{\circ} \mathrm{C}$

\begin{tabular}{lcccc}
\hline \multirow{2}{*}{ Tested fungi } & \multicolumn{3}{c}{ Tested bacilli } & Control of tested \\
\cline { 2 - 4 } & Bacillus subtilis & $\begin{array}{c}\text { Bacillus } \\
\text { thuringiensis }\end{array}$ & Bacillus mycoides & \\
\hline Aspergillus ochraceus & $3.59 \pm 2.24^{\mathrm{a}}$ & $2.17 \pm 2.25^{\mathrm{a}}$ & $3.92 \pm 0.55^{\mathrm{a}}$ & $23.00 \pm 0.00^{\mathrm{b}}$ \\
Aspergillus westerdijkiae & $13.30 \pm 1.59^{\mathrm{b}}$ & $18.52 \pm 0.97^{\mathrm{c}}$ & $5.73 \pm 5.34^{\mathrm{a}}$ & $17.28 \pm 0.28^{\mathrm{b}}$ \\
Aspergillus flavus & $3.05 \pm 3.07^{\mathrm{a}}$ & $2.73 \pm 4.04^{\mathrm{a}}$ & $34.58 \pm 1.34^{\mathrm{b}}$ & $36.00 \pm 0.00^{\mathrm{b}}$ \\
Aspergillus parasiticus & $27.83 \pm 11.70^{\mathrm{ab}}$ & $36.00 \pm 0.00^{\mathrm{b}}$ & $21.34 \pm 7.38^{\mathrm{a}}$ & $36.00 \pm 0.00^{\mathrm{ab}}$ \\
\hline Legend: $*$ - data in the columns followed by the same letter are not significantly different in $95.0 \%$ Tukey HSD test, SD
\end{tabular}

- standard deviation

B. mycoides showed the best inhibitory ability against ochratoxigenic aspergilli. The percentage of mycelial growth inhibition $(\%)$ calculated after all days of cultivation ( 8 days) with comparison to control sets was $67.36 \%$ for $A$ westerdijkiae and $82.96 \%$ for A. ochraceus (Fig. 4). From the tested fungi, $A$. ochraceus was the most sensitive to the action of all Bacillus species (Fig. 5B). The most potent inhibition against this isolate exhibited $B$. subtillis (growth inhibition rate $91.54 \%$ ) followed by $B$. thuringiensis (growth inhibition rate 90.55 $\%$ ) and $B$. mycoides (growth inhibition rate $82.96 \%$ ). The sensitivity of A. flavus isolate was lower compared to $A$. ochraceus, but its growth was significantly inhibited by $B$. thuringiensis (growth inhibition rate $92.43 \%$ ) and B. subtilis (growth inhibition rate 91.54\%) compared to the control sets (Fig. 5A). Similar results with Bacillus subtillis against $S$. rolfsii obtained by authors Rajkumar et al. (2018) and Nayak et al. (2020) in their study found that Bacillus spp. were able to inhibit the growth of A. flavus up to more than $90 \%$. A very poor inhibition effect was observed using the dual culture method with $B$. thuringiensis and $A$. westerdijkiae. B. thuringiensis inhibited the growth of this isolate only up to the sixth day of cultivation $(\varnothing 8.97 \mathrm{~mm})$ compared to control $(\varnothing 13.71 \mathrm{~mm})$. After the cultivation period ( 8 days), the diameters of $A$. westerdijkiae colonies were larger $(18.52 \pm 0.97 \mathrm{~mm})$ than the colony diameters of control sets $(17.28 \pm 0.28 \mathrm{~mm})$. So, its growth was moderately stimulated by $B$. thuringiensis.

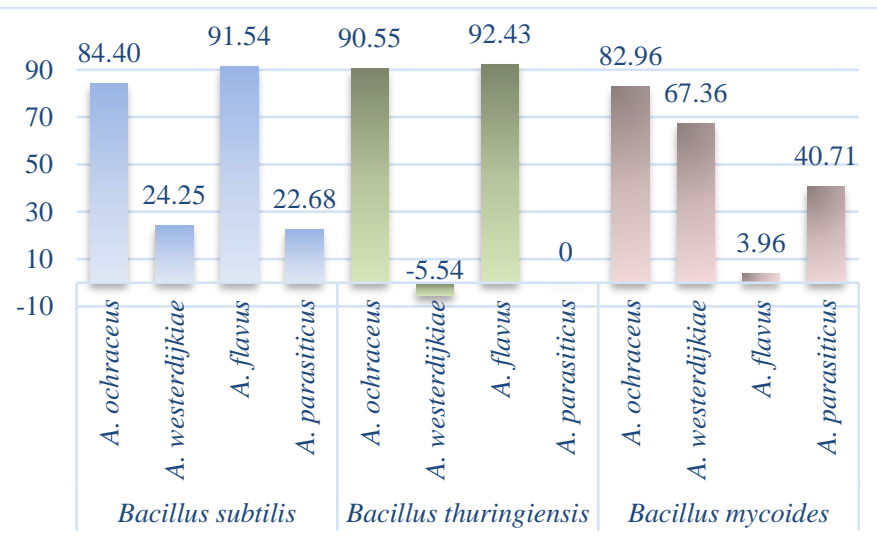

Figure 4 The percentage of mycelial growth inhibition PMGI (\%) of the tested fungi by Bacillus species after 8 days of dual culture in the dark at $30^{\circ} \mathrm{C}$ ) 


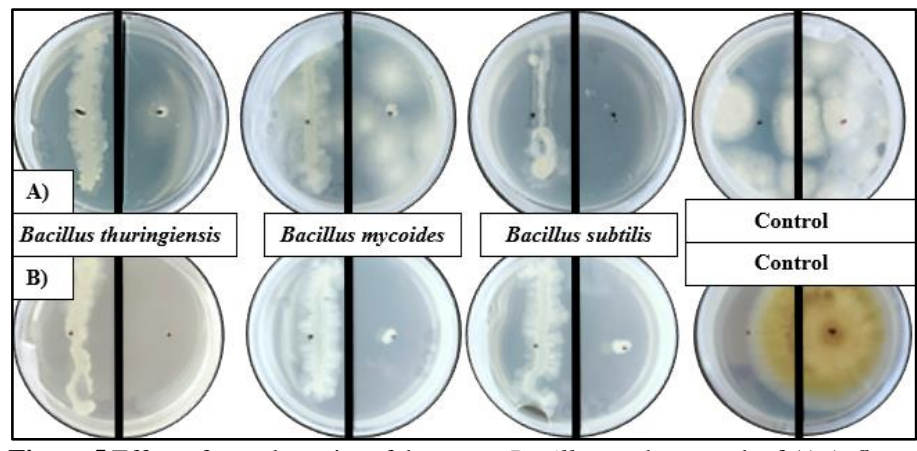

Figure 5 Effect of tested species of the genus Bacillus on the growth of A) A. flavus and B) A. ochraceus, by the dual culture method, after 8 days of cultivation in the dark at $30^{\circ} \mathrm{C}$

Based on the results, can be concluded that the coincubation method was better than dual culture method used. In the case of aflatoxigenic aspergilli, the difference between two used methods in the action of Bacillus spp. were observed. Significant and stronger antagonistic effects of selected species of the genus Bacillus could be seen mainly in the case of A. flavus and A. parasiticus used coincubation method in comparison with the dual culture method. The different effects of bacteria in the case of coincubation method, which were resulted in a higher inhibition of fungal growth, may be due to the use of a more suitable culture medium for bacteria, and fungi, respectively. The more appropriate used medium in coincubation method may have affected the potential production of Bacillus spp. volatile compounds, and since the bacteria did not come into direct contact with fungi, can be assume that the highest growth inhibition was due to their production. Also, Morita et al (2019) studied the antifungal effect of Bacillus pumillus volatiles by cultivating fungi and bacteria on three different media: Trypt-Soya agar (TSA), Lauria-Betan agar (LBA) and TM Enterprise agar (TMES). They found that the bacterium grown showed the strongest inhibition effect against Penicillium italicum only on TMEA medium. Tyc et al. (2017) report, that the volatile organic compounds produced by Bacillus spp. can easily evaporate and diffuse through pores filled with air and water. Due to these physicochemical properties, volatile substances are ideal candidates for cooperation or antagonism between soil microorganisms that do not live directly next to each other.

\section{Inhibitory effect of Bacillus spp. on mycotoxin production}

Bacillus spp. volatiles not only inhibited the vegetative growth but also affected the mycotoxin production of toxigenic fungi. Although some species of the genus Bacillus did not completely inhibit the growth of the tested fungi, but they were able to suppress the production of their mycotoxins, especially in the case of inhibition of ochratoxin a (OTA) production. All three bacterial isolates inhibited OTA production by $A$. westerdijkiaae and A. ochraceus totally (100\%) in comparison with control sets. Successful inhibition of mycotoxin biosynthesis was also observed in the case of reversible action of Bacillus spp., when 5 days exposure of microscopic fungi to bacterial volatiles was sufficient to completely inhibit their toxigenic potential (Table 3). The effect of bacterial VOCs, specifically of $B$. licheniformis $350-2$ on OTA synthesis was tested after the $10^{\text {th }}$ day of coincubation in study of Ul Hassan et al. (2019). Their results showed complete inhibition of OTA synthesis by toxigenic fungi $A$. westerdijkiae BA1, $A$. carbonarius MG7 and P verrucosum MC12. Nevertheless, A. ochraceus MD1 $(21.84 \mu \mathrm{g} / \mathrm{kg})$ and A. niger MC5 $(29.32 \mu \mathrm{g} / \mathrm{kg})$ were still able to produce OTA in the presence of bacterial volatiles, although the levels of OTA produced were significantly lower than the levels of OTA production of the unexposed control $(A$ ochraceus MD1 - 87.21 $\pm 6.32 \mu \mathrm{g} / \mathrm{kg}$, A. niger MC5- $75.44 \pm 7.90 \mu \mathrm{g} / \mathrm{kg}$ ). Einloft et al. (2017) also showed a reduction in the production of $A$. westerdijkiae OTA production by bacterial antagonists of $B$. safensis RF69, B. amyloliquefaciens RP103 and B. subtilis RP242 ranging from 62 to $96 \%$. Some other authors have confirmed the inhibition of ochratoxin A by volatiles of Bacillus spp. (Jiang et al. 2017; Shukla et al., 2020; Higazy et al., 2021).

Table 3 Effect of bacterial volatiles produced by Bacillus spp. on the mycotoxin biosynthesis of tested toxigenic aspergilli $(\mathrm{n}=6)$ after coincubation and reversibility method

\begin{tabular}{|c|c|c|c|c|c|}
\hline \multicolumn{6}{|l|}{ Coincubation } \\
\hline Tested aspergilli & mycotoxin & Bacillus subtilis & Bacillus mycoides & Bacillus thuringiensis & Control \\
\hline A. ochraceus & $\mathrm{OA}$ & nd & nd & nd & $6 / 6$ \\
\hline A. westerdijkiae & $\mathrm{OA}$ & nd & nd & nd & $6 / 6$ \\
\hline A. flavus & $\mathrm{AFB}_{1}$ & $1 * * / 6 *$ & $1 / 6$ & $0 / 6$ & $6 / 6$ \\
\hline \multirow{2}{*}{ A. parasiticus } & $\mathrm{AFB}_{1}$ & $3 / 6$ & $0 / 6$ & $2 / 6$ & \multirow[b]{2}{*}{$6 / 6$} \\
\hline & $\mathrm{AFG}_{1}$ & $3 / 6$ & $0 / 6$ & $1 / 6$ & \\
\hline \multicolumn{6}{|l|}{ Reversibility } \\
\hline A. ochraceus & $\mathrm{OA}$ & nd & nd & nd & $6 / 6$ \\
\hline A. westerdijkiae & $\mathrm{OA}$ & nd & nd & nd & $6 / 6$ \\
\hline A. flavus & $\mathrm{AFB}_{1}$ & $2 / 6$ & $1 / 6$ & $0 / 6$ & $6 / 6$ \\
\hline \multirow{2}{*}{ A. parasiticus } & $\mathrm{AFB}_{1}$ & $4 / 6$ & $0 / 6$ & $2 / 6$ & \multirow{2}{*}{$6 / 6$} \\
\hline & $\mathrm{AFG}_{1}$ & $4 / 6$ & $0 / 6$ & $2 / 6$ & \\
\hline
\end{tabular}

Legend: nd - mycotoxin not detected (below the limit of detection of the TLC method), OA - ochratoxin $\mathrm{A}, \mathrm{AFB}_{1}-$ aflatoxin

$\mathrm{B}_{1}, \mathrm{AFG}_{1}$ - aflatoxin $\mathrm{G}_{1}$, ** - number of mycotoxins produced isolates, * - number of tested isolates

B. thuringiensis demonstrated the best antitoxigenic potential against AFB production by $A$. flavus. Its production was completely inhibited even in the case of tested reversibility. Kong et al. (2014) found that aflatoxin accumulation was totally (more than $98 \%$ ) inhibited and cause the down-regulation of the aflatoxin genes by co-cultivation with $B$. megaterium. The biosynthesis of $\mathrm{AFB}_{1}$ and $\mathrm{AFG}_{1}$ produced by $A$. parasiticus totally inhibited only $B$. mycoides in all repetitions. $B$ subtilis inhibited the production of $\mathrm{AFB}_{1}$ and $\mathrm{AFG}_{1}$ produced by $A$. parasiticus a least. In the case of coincubation was able to suppress the production these aflatoxins only in half replicates, and in the case of a reversible effect the production of these mycotoxins was observed in up to 4 replicates. Better results with $B$. subtilis obtained Siahmoshteh et al. (2018). In their study B. subtilis was able to suppress $A$. parasiticus aflatoxins production up to $100 \%$ and the degradation of aflatoxins has been proved after two days of co-cultivation the fungal strain with bacteria.

\section{CONCLUSION}

In summary, the results obtained in this study represent the promising characteristics of Bacillus spp. to be used as biocontrol agents of toxigenic fung of genus Aspergillus. The antagonistic activity of Bacillus spp. was evaluated using two different methods (coincubation and dual culture technique), where some differences were observed, especially in the case of growth inhibition of aflatoxigenic isolates. Our findings demonstrated that the coincubation method showed increased inhibitory efficiency. Among all fungal isolates, we observed the strongest inhibitory effect in the case of Bacillus spp. on the growth of $A$ ochraceus in both coincubation and dual culture methods, respectively. This fungal isolate was indicated as the most sensitive compared to the related species $(A$ westerdijkiae) and the aflatoxigenic species. Antitoxinogenic properties of
Bacillus spp. by using coincubation method were very effective, mainly in inhibition of ochratoxin production, but also had the potential to inhibit aflatoxins synthesis. Our research confirmed the antagonistic abilities of Bacillus spp. agains microscopic fungi, contaminating many crops and food. Their bioprotective character and their volatile compounds have also been confirmed in many in vivo and in situ assays. Therefore, these results suggest the potential application of Bacillus spp. for the preservation of food commodities, and further studies should be carried out to develop the commercial usage of the selected biocontrol agents of the genus Bacillus.

Acknowledgments: This work was supported by Slovak Research and Development Agency under Contract no. APVV-16-0173. The authors wish to thank Mgr. Dominika Vešelenyiová, PhD. for the language editing.

\section{REFERENCES}

Abdolmaleki, K., Khedri, S., Alizadeh, L., Javanmardi, F., Oliveira, C. A., \& Khaneghah, A. M. (2021). The mycotoxins in edible oils: An overview of prevalence, concentration, toxicity, detection and decontamination techniques. Trends in Food Science \& Technology, 115, 500-511. https://doi.org/10.1016/j.tifs.2021.06.057

Arfaoui, M., Vallance, J., Bruez, E., Rezgui, A., Melki, I., Chebil, S., ... \& Rey, P. (2019). Isolation, identification, and in vitro characterization of grapevine rhizobacteria to control ochratoxigenic Aspergillus spp. on grapes. Biological Control, 129, 201-211. https://doi.org/10.1016/j.biocontrol.2018.10.019

Badiale Furlong, E., Badiale Furlong, V., Kupski, L., Scaglioni, P. T., Denardi de Souza, T., \& Christ-Ribeiro, A. (2021). Use of natural resources from Southern Brazil as a strategy to mitigate fungal contamination. Critical reviews in food 
science and nutrition, 61(2), 275-282 https://doi.org/10.1080/10408398.2020.1726868

Císarová, M., Hleba, L., Medo, J., Tančinová, D., Mašková, Z., Čuboň, J., ... \& Klouček, P. (2020). The in vitro and in situ effect of selected essential oils in vapour phase against bread spoilage toxicogenic aspergilli. Food Control, 110 107007. https://doi.org/10.1016/j.foodcont.2019.107007

Císarová, M., Tančinová, D., \& Brodová, M. (2015). Antifungal activity of volatile components generated by essential oils against the genus Penicillium isolated from bread samples. Journal of Microbiology, Biotechnology and Food Sciences, 4(special 1), 1-5. https://doi.org/10.15414/jmbfs.2015.4.special1.1-5

Einloft, T. C., Oliveira, P. B. D., Veras, F. F., Welke, J. E., Mallmann, C. A., Dilkin, P., \& Dionello, R. G. (2017). Effect of Bacillus spp. on Aspergillus westerdijkiae growth, sporulation and ochratoxin A production in green-coffee medium. Food Science and Technology, 37, 24-27. https://doi.org/10.1590/1678457X.05617

Fiori, S., Urgeghe, P. P., Hammami, W., Razzu, S., Jaoua, S., \& Migheli, Q. (2014). Biocontrol activity of four non-and low-fermenting yeast strains against Aspergillus carbonarius and their ability to remove ochratoxin A from grape juice. International journal of food microbiology, 189, 45-50 https://doi.org/10.1016/j.ijfoodmicro.2014.07.020

Fira, D., Dimkić, I., Berić, T., Lozo, J., \& Stanković, S. (2018). Biological control of plant pathogens by Bacillus species. Journal of biotechnology, 285, 44-55. https://doi.org/10.1016/j.jbiotec.2018.07.044

Foysal, M. J., \& Lisa, A. K. (2018). Isolation and characterization of Bacillus sp. strain $\mathrm{BC} 01$ from soil displaying potent antagonistic activity against plant and fish pathogenic fungi and bacteria. Journal of Genetic Engineering and Biotechnology, 16(2), 387-392. https://doi.org/10.1016/j.jgeb.2018.01.005

Frisvad, J. C., Hubka, V., Ezekiel, C. N., Hong, S. B., Nováková, A., Chen, A. J.,

.. \& Houbraken, J. (2019). Taxonomy of Aspergillus section Flavi and their production of aflatoxins, ochratoxins and other mycotoxins. Studies in mycology, 93, 1-63. https://doi.org/10.1016/j.simyco.2018.06.001

Garcia-Rubio, R., de Oliveira, H. C., Rivera, J., \& Trevijano-Contador, N. (2020). The fungal cell wall: Candida, Cryptococcus, and Aspergillus species. Frontier in microbiology, 10, 2993. https://doi.org/10.3389/fmicb.2019.02993

Gong, Q., Zhang, C., Lu, F., Zhao, H., Bie, X., \& Lu, Z. (2014). Identification of bacillomycin D from Bacillus subtilis fmbJ and its inhibition effects against Aspergillus flavus. Food Control, $36(1), \quad 8-14$ https://doi.org/10.1016/j.foodcont.2013.07.034

Higazy, N. S., Saleh, A. E., Hassan, Z. U., Al Thani, R., Migheli, Q., \& Jaoua, S (2021). Investigation and application of Bacillus pumilus QBP344-3 in the contro of Aspergillus carbonarius and ochratoxin A contamination. Food Control, 119 107464. https://doi.org/10.1016/j.foodcont.2020.107464

Hleba, L., Kmet', V., Tóth, T., \& Kačániová, M. (2017). Resistance in bacteria and indirect beta-lactamase detection in E. coli isolated from Culex pipiens detected by matrix-assisted laser desorption ionization time of flight mass spectrometry. Journal of Environmental Science and Health, Part B, 52(1), 64-69. https://doi.org/10.1080/03601234.2016.1229466

Chaves-López, C., Serio, A., Gianotti, A., Sacchetti, G., Ndagijimana, M., Ciccarone, C., ... \& Paparella, A. (2015). Diversity of food-borne Bacillus volatile compounds and influence on fungal growth. Journal of applied microbiology, 119(2), 487-499. https://doi.org/10.1111/jam.12847

Chen, A. J., Hubka, V., Frisvad, J. C., Visagie, C. M., Houbraken, J., Meijer, M.,

\& Samson, R. A. (2017). Polyphasic taxonomy of Aspergillus section Aspergillus (formerly Eurotium), and its occurrence in indoor environments and $\begin{array}{lllll}\text { food. Studies in } & \text { Mycology, } & \text { 88, } & \text { 37-135. }\end{array}$ https://doi.org/10.1016/j.simyco.2017.07.001

Chen, W., Li, C., Zhang, B., Zhou, Z., Shen, Y., Liao, X., ... \& Shen, X. L. (2018) Advances in biodetoxification of ochratoxin AA review of the past five decades Frontiers in microbiology, 9, 1386. https://doi.org/10.3389/fmicb.2018.01386 Islam, M. T., Rahman, M. M., Pandey, P., Boehme, M. H., \& Haesaert, G. (Eds.) (2019). Bacilli and agrobiotechnology: phytostimulation and biocontrol. Springer (335 p.)

Jiang, C., Chen, X., Lei, S., Zhao, H., Liu, Y., \& Shi, J. (2017). Lipopeptides from Bacillus subtilis have potential application in the winemaking process: inhibiting fungal and ochratoxin A contamination and enhancing esters and acids biosynthesis. Australian journal of grape and wine research, 23(3), 350-358. https://doi.org/10.1111/ajgw.12289

Jiang, C., Shi, J., Liu, Y., \& Zhu, C. (2014). Inhibition of Aspergillus carbonarius and fungal contamination in table grapes using Bacillus subtilis. Food Control, 35(1), 41-48. http://dx.doi.org/10.1016/j.foodcont.2013.06.054

Karlovsky, P., Suman, M., Berthiller, F., De Meester, J., Eisenbrand, G., Perrin, I.,

\& Dussort, P. (2016). Impact of food processing and detoxification treatments on mycotoxin contamination. Mycotoxin research, 32(4), 179-205. https://doi10.1007/s12550-016-0257-7

Kong, Q., Chi, C., Yu, J., Shan, S., Li, Q., Li, Q., ... \& Bennett, J. W. (2014). The inhibitory effect of Bacillus megaterium on aflatoxin and cyclopiazonic acid biosynthetic pathway gene expression in Aspergillus flavus. Applied microbiology and biotechnology, 98(11), 5161-5172. https://doi10.1007/s00253-014-5632-8 Labuda, R., \& Tančinová, D. (2006). Mykotická kontaminácia vybraných surovín rastlinného pôvodu. Bojňanská, T. et al. Výživná a technologická kvalita rastlinných produktov a ich potravinárske využitie (Nutritional and technological quality of plant products and their use in food industry). Nitra: SPU Nitra, 167194.

Lastochkina, O., Seifikalhor, M., Aliniaeifard, S., Baymiev, A., Pusenkova, L., Garipova, S., ... \& Maksimov, I. (2019). Bacillus spp.: efficient biotic strategy to control postharvest diseases of fruits and vegetables. Plants, 8(4), 97 https://doi.org/10.3390/plants8040097

Lorenzo, J. M., Munekata, P. E., Dominguez, R., Pateiro, M., Saraiva, J. A., \& Franco, D. (2018). Main groups of microorganisms of relevance for food safety and stability: general aspects and overall description. Innovative technologies for food preservation (pp. 53-107). Academic Press. https://doi.org/10.1016/B978-0 12-811031-7.00003-0

Morita, T., Tanaka, I., Ryuda, N., Ikari, M., Ueno, D., \& Someya, T. (2019) Antifungal spectrum characterization and identification of strong volatile organic compounds produced by Bacillus pumilus TM-R. Heliyon, 5(6), e01817. https://doi.org/10.1016/j.heliyon.2019.e01817

Nath, S., Chowdhury, S., \& Dora, K. C. (2015). Application of Bacillus sp. as a biopreservative for food preservation. International Journal of Engineering Research and Applications, 5(4), 85-95.

Nayak, S., Dhua, U., \& Samanta, S. (2020). Antagonistic activity of cowshed Bacillus sp. bacteria against aflatoxigenic and sclerotic Aspergillus flavus. Journa of Biological Control, 34(1), 52-58. https://doi.org/10.18311/jbc/2020/24839

Neme, K., \& Mohammed, A. (2017). Mycotoxin occurrence in grains and the role of postharvest management as a mitigation strategies. A review. Food Control, 78, 412-425. https://doi.org/10.1016/i.foodcont.2017.03.012

Petchkongkaew, A., Taillandier, P., Gasaluck, P., \& Lebrihi, A. (2008). Isolation of Bacillus spp. from Thai fermented soybean (Thua-nao): screening for aflatoxin B1 and ochratoxin A detoxification. Journal of Applied Microbiology, 104(5), 1495-1502. https://doi.org/10.1111/j.1365-2672.2007.03700.x

Rajkumar, K., Naik, M. K., Amaresh, Y. S., \& Chennappa, G. (2018). In vitro Screening of Bacillus subtilis Isolates against Sclerotium rolfsii Cause for Collar Rot of Chilli. Int. J. Curr. Microbiol. App. Sci, 7(7), 2687-2692. https://doi.org/10.20546/ijcmas.2018.707.315

Ramos-Pereira, J., Mareze, J., Fernández, D., Rios, E. A., Santos, J. A., \& LópezDíaz, T. M. (2021). Antifungal activity of lactic acid bacteria isolated from milk against Penicillium commune, $P$. nordicum, and $P$. verrucosum. International Journal of Food Microbiology, 355, 109331 https://doi.org/10.1016/j.ijfoodmicro.2021.109331

Ren, X., Zhang, Q., Zhang, W., Mao, J., \& Li, P. (2020). Control of aflatoxigenic molds by antagonistic microorganisms: Inhibitory behaviors, bioactive compounds, related mechanisms, and influencing factors. Toxins, 12(1), 24 https://doi.org/10.3390/toxins12010024

Sadiq, F. A., Yan, B., Tian, F., Zhao, J., Zhang, H., \& Chen, W. (2019). Lactic acid bacteria as antifungal and anti-mycotoxigenic agents: a comprehensive review. Comprehensive Reviews in Food Science and Food Safety, 18(5), 1403-1436. https://doi.org/10.1111/1541-4337.12481

Saleh, A. E., Ul-Hassan, Z., Zeidan, R., Al-Shamary, N., Al-Yafei, T., Alnaimi, H., ... \& Jaoua, S. (2021). Biocontrol Activity of Bacillus megaterium BM344-1 against Toxigenic Fungi. ACS omega, 6(16), 10984-10990 https://doi.org/10.1021/acsomega.1c00816

Saleh, A., \& Jaoua, S. (2020). Biocontrol Activities of Bacillus megaterium Volatile Organic Compounds (VOCs) Against Mycotoxigenic Aspergillus, Penicillium and Fusarium fungi. Qatar University, Theme 1: Energy, Environment \& Resource Sustainability. https://doi.org/10.29117/quarfe.2020.0092

Samson, R. A., Hoekstra, E. S., Frisvad, J. C., \& Filtenborg, O. (2002). Introduction to Food and Airborne Fungi. Urecht: Centraalbureau voor Schimmelcultures (pp. 283-297). ISBN 90-70351-42-0. https://doi.org/10.1007/s11046-005-4201-1

Shukla, S., Park, J. H., \& Kim, M. (2020). Efficient, safe, renewable, and industrially feasible strategy employing Bacillus subtilis with alginate bead composite for the reduction of ochratoxin A from wine. Journal of Cleaner Production, 242, 118344. https://doi.org/10.1016/j.jclepro.2019.118344

Siahmoshteh, F., Hamidi-Esfahani, Z., Spadaro, D., Shams-Ghahfarokhi, M., \& Razzaghi-Abyaneh, M. (2018). Unraveling the mode of antifungal action of Bacillus subtilis and Bacillus amyloliquefaciens as potential biocontrol agents against aflatoxigenic Aspergillus parasiticus. Food Control, 89, 300-307. https://doi.org/10.1016/i.foodcont.2017.11.010

Taniwaki, M. H., Pitt, J. I., \& Magan, N. (2018). Aspergillus species and mycotoxins: occurrence and importance in major food commodities. Current Opinion in Food Science, 23, 38-43. https://doi.org/10.1016/j.cofs.2018.05.008

Touré, Y., Ongena, M. A. R. C., Jacques, P., Guiro, A., \& Thonart, P. (2004). Role of lipopeptides produced by Bacillus subtilis GA1 in the reduction of grey mould disease caused by Botrytis cinerea on apple. Journal of applied microbiology, 96(5), 1151-1160. https://doi.org/10.1111/j.1365-2672.2004.02252.x

Tyc, O., Song, C., Dickschat, J. S., Vos, M., \& Garbeva, P. (2017). The ecological role of volatile and soluble secondary metabolites produced by soil bacteria Trends in microbiology, 25(4), 280-292. https://doi.org/10.1016/j.tim.2016.12.002 Ul Hassan, Z., Al Thani, R., Alnaimi, H., Migheli, Q., \& Jaoua, S. (2019). Investigation and application of Bacillus licheniformis volatile compounds for the 
biological control of toxigenic Aspergillus and Penicillium spp. ACS omega 4(17), 17186-17193. https://doi.org/10.1021/acsomega.9b01638

Wang, J., Liu, J., Chen, H., \& Yao, J. (2007). Characterization of Fusarium graminearum inhibitory lipopeptide from Bacillus subtilis IB. Applied Microbiology and Biotechnology, 76(4), 889-894. https://doi10.1007/s00253-0071054-1

Yamairi, K., Ido, K., Nakamura, S., Niki, M., Imoto, W., Shibata, W., ... \& Kakeya, H. (2019). Successful treatment of invasive pulmonary aspergillosis caused by Aspergillus felis, a cryptic species within the Aspergillus section Fumigati: a case report. Journal of Infection and Chemotherapy, 25(4), 307-310. https://doi.org/10.1016/j.jiac.2018.10.016

Zhang, H., Serwah Boateng, N. A., Ngolong Ngea, G. L., Shi, Y., Lin, H., Yang, Q., ... \& Droby, S. (2021). Unravelling the fruit microbiome: The key for developing effective biological control strategies for postharvest diseases Comprehensive Reviews in Food Science and Food Safety, 20, 4906-4930. https://doi.org/10.1111/1541-4337.12783

Zhang, X., Guo, X., Wu, C., Li, C., Zhang, D., \& Zhu, B. (2020). Isolation, heterologous expression, and purification of a novel antifungal protein from Bacillus subtilis strain Z-14. Microbial Cell Factories, 19(1), 1-10. https://doi.org/10.1186/s12934-020-01475-1 